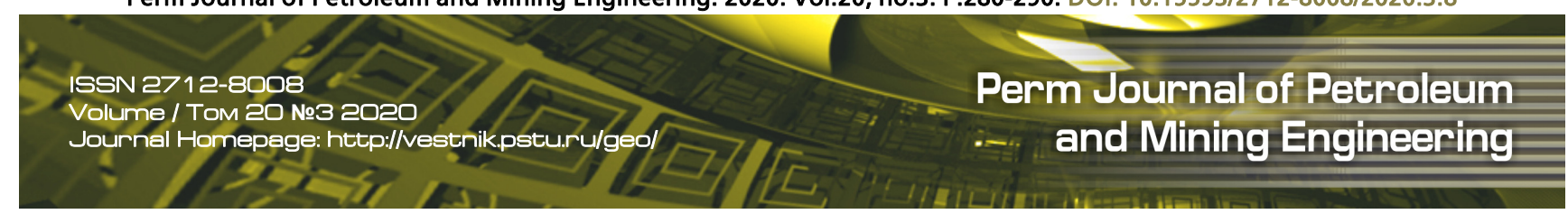

UDC 622.4

Article / Статья

(c) PNRPU / ПНИПУ, 2020

\title{
Ensuring Occupational Safety and Health through Ventilation in Underground Mines with Internal Combustion Engine Vehicles on Duty
}

\section{Evgeniy L. Grishin, Artem V. Zaitsev, Evgeniy G. Kuzminykh}

Federal State Budgetary Institution of Science Mining Institute of the Ural Branch of the Russian Academy of Sciences (78a Sibirskaya st., Building A, Perm, 614007, Russian Federation)

\section{Обеспечение безопасных условий деятельности сотрудников по фактору вентиляция в подземных рудниках при работе техники, оснащенной двигателями внутреннего сгорания}

\section{Е.Л. Гришин, А.В. Зайцев, Е.Г. Кузьминых}

Горный институт Уральского отделения Российской академии наук (Россия, 614007, г. Пермь, ул. Сибирская, 78а)

\section{Received / Получена: 03.02.2020. Accepted / Принята: 15.06.2020. Published / Опубликована: 17.08.2020}

\section{Keywords:}

regulatory documentation, mine, diesel fuel, exhaust gas components, internal combustion engine, emission standard, oxygen concentration, required air quantity.
Ключевые слова: нормативная документация, рудник, дизельное топливо, компоненты выхлопных газов, двигатель внутреннего сгорания, норма выбросов, концентрация кислорода, требуемое количество воздуха.
Increasing production capacities and developing ventilation systems in underground mines challenge mining enterprises to enhance the output level of applied mining and ventilation facilities. Most of the rock loading and transporting mining machinery at ore deposits is powered by diesel internal combustion engines. Insufficient ventilation or wrong approaches to determining the amount of air required to dilute the main components of exhaust gases from internal combustion engines, including carbon monoxide and nitrogen oxides, can result in poisoning or even death of mining workers. However, most production facilities make their ventilation systems operate at the capacity limits without any opportunities to increase their technical reserves. This fact has a direct impact on safety of mining operations. We present methods and equations aimed at determining the required air quantity for the operating areas of the vehicles equipped with internal combustion engines and the underground mines at their designing and operation stages.

The analysis of regulatory documentation shows that there is no requirement to airflow rate per power unit of internal combustion engines. Therefore, we propose an approach that meets up-to-date industrial safety requirements based on the actual emissions of harmful components, performance parameters of internal combustion engines and emission standards guaranteed by manufacturers though confirming an engine's emission class compliance. The proposed methods will allow us to enhance workplace safety at underground mines where internal combustion engine equipment is on duty, and to increase the efficiency of designing new blocks, horizons and mines by eliminating unreasonable reserves when selecting mining and ventilation equipment.

Увеличение производственных мощностей и развитие вентиляционных сетей подземных рудников ставят перед горными предприятиями задачи повышения мощности применяемого горного и вентиляционного оборудования. Большинство горного оборудования для погрузки и транспортировки горной породы на рудных месторождениях работает на базе техники с дизельными двигателями внутреннего сгорания. Недостаточная вентиляция или неправильный подход к расчету необходимого количества воздуха для разбавления основных компонентов выхлопных газов от двигателей внутреннего сгорания, таких как угарный газ и окислы азота, могут привести к отравлению или даже гибели горных рабочих. Однако на большинстве современных предприятий вентиляционное оборудование работает на пределах технической возможности - без вероятности увеличения технического резерва. Этот факт, в свою очередь, напрямую влияет на безопасность ведения горных работ. Представлены методы и зависимости для расчета требуемого количества воздуха для рабочих зон машин, оснащенных двигателями внутреннего сгорания, подземных рудников при их проектировании и эксплуатации.

Анализ нормативной литературы показывает, что в настоящее время отсутствует требуемая норма расхода воздуха на единицу мощности двигателя внутреннего сгорания. Поэтому предлагается подход, соответствующий современным требованиям промышленной безопасности, основанный на фактических выбросах вредных компонентов, параметрах работы двигателей внутреннего сгорания и нормах выбросов, гарантируемых производителем путем подтверждения соответствия двигателя экологическому классу. Предлагаемые методы позволят повысить безопасность на рабочих местах при работе техники с двигателями внутреннего сгорания на подземных рудниках, а также увеличить эффективность проектирования новых блоков, горизонтов и рудников за счет исключения необоснованного резерва при подборе горного и вентиляционного оборудования.

Evgeniy L. Grishin (Author ID in Scopus: 54895072600) - PhD in Engineering, Researcher at the Department of Aerology and Thermophysics (tel.: + 0079127865315 , e-mail: aeroevg@mail.ru).

Artem V. Zaitsev (Author ID in Scopus: 57213120380) - Doctor of Engineering, Researcher at the Department of Aerology and Thermophysics (tel.: + 0079824873412 , e-mail: aerolog.artem@gmail.com).

Evgeniy G. Kuzminykh - PhD student at the Department of Aerology and Thermophysics (tel.: + 007982496 39 27, e-mail: kuzminykh.evgeniy@gmail.com). The contact person for correspondence.

Гришин Евгений Леонидович - научный сотрудник отдела аэрологии и теплофизики, кандидат технических наук (тел.: + 007912 786 5315 , e-mail: aeroevg@mail.ru). Зайцев Артем Вячеславович - научный сотрудник отдела аэрологии и теплофизики, доктор технических наук (тел.: + 0079824873412 , e-mail: aerolog.artem@gmail.com). Кузьминых Евгений Геннадьевич - аспирант отдела аэрологии и теплофизики (тел.: + 007982496 39 27, e-mail: kuzminykh.evgeniy@gmail.com). Контактное лицо для переписки. 


\section{Introduction}

Currently, mining industry is facing a range of issues in the development of mineral deposits. The increasing demand for mineral resources, stringent enforcement of regulatory and environmental laws, complexity of mining conditions and many other factors pose challenges to mining enterprises, which influence profitability of companies and safety of personnel.

Increasing production capacities aimed at meeting demands for more mineral resources entail the development of new mining sites located at great depths or at significant distances from main openings, as well as the increase in the inventory or capacities of mining machinery. Most mining mobile equipment for loading and transporting rocks at ore deposits is powered by diesel internal combustion engines (ICE). Insufficient ventilation or wrong determination of the amount of air required to dilute the main components of exhaust gases from internal combustion engines, including carbon monoxide and nitrogen oxides, can result in poisoning or even death of mining workers. However, at most production facilities, ventilation systems operate at the capacity limits with no possibility of increasing the technical reserve. This fact has a direct impact on safety of mining operations.

Therefore, it is crucial to determine the amount of air required to dilute the harmful and hazardous components of exhaust gases emitted from the machinery equipped with internal combustion engines to safe concentrations.

\section{Regulatory Documentation}

In the 20th century, especially in the postwar period, the mining industry was advancing at a rapid pace. The development of diesel technology contributed to mechanisation of mining operations. In this connection, regulations were developed to improve the industrial safety.

Earlier, Uniform Safety Requirements for Underground Development of Ore, Non-Ore, and Placer Mineral Deposits (PB code 06-111-95) regulated the rate of fresh air supply in mine workings with internal combustion engine machinery on duty in an amount that reduces the concentration of harmful exhaust products in the mine atmosphere to meet the health and safety standards, but not less than $5 \mathrm{~m}^{3} / \mathrm{min}$ per $1 \mathrm{HP}$ of diesel engine power rating and $6 \mathrm{~m}^{3} / \mathrm{min}$ of petrol engine power rating [1]. In 2003, the Uniform Safety Requirements [1] were cancelled to be replaced by a new version. However, the standard requirements of the fresh air supply that reduces the concentration of harmful exhaust products in the mine atmosphere were removed.

At present. Norms of Technological Design of Mining Enterprises of Metallurgy with Underground Mining Method (VNTP code 13-2-93) are one of the regulatory documents, stipulating the standards of fresh air supply for diluting exhaust gas components of $5 \mathrm{~m}^{3} / \mathrm{min}$ per $1 \mathrm{HP}$ of an engine power [2]. VNTP 13-2-93 standard is not strictly binding due to the fact that it is not registered with the Ministry of Justice of Russia, and in accordance with Paragraph 10 of the Presidential Decree No. 763 of Mav 23. 1996 On the Procedure for the Publication and Entrv into Force of Acts of the President of the Russian Federation, the Government of the Russian Federation and regulatory legal acts of federal executive bodies serve as guidelines only.

It should be noted, that it is not only in the Russian regulatory documentation that the rate of fresh air supply per $1 \mathrm{HP}$ of engine power for the dilution of the exhaust gas components to the maximum permissible concentrations is stipulated. Table 1 shows a comparison of the standards of some countries with a high level of mining industry [3-11].

For a long time, the Russian standard was the only regulation used to determine the required air quantity for the operating areas of internal combustion engine vehicles. However, after the technological development and introduction of emission standards for internal combustion engines, this standard became obsolete and could only serve as guidelines.

Currently, the dilution requirements for exhaust gases of internal combustion engines in the mining industry are specified in Paragraphs

Table 1

Comparison of fresh air supply standards

\begin{tabular}{lc}
\hline \multicolumn{1}{c}{ Country } & $\begin{array}{c}\text { Conditional fresh air supply } \\
\text { limit, } \mathrm{m}^{3} / \mathrm{min} \text { per } 1 \mathrm{HP}\end{array}$ \\
\hline Australia & $4.2-5$ \\
\hline Canada & $4.0-7.7$ \\
\hline USA & 5.0 \\
\hline Chile & 5.3 \\
\hline China & 5.5 \\
\hline South Africa & 5.0 \\
\hline Russian Federation & 5.0 \\
\hline
\end{tabular}


$\mathrm{CO}$ and NOx emission limits for diesel engines in off-road vehicles according to the USA and EU toxicity standards, $\mathrm{g} / \mathrm{kWh}$

\begin{tabular}{|c|c|c|c|c|c|c|c|}
\hline \multicolumn{4}{|c|}{ USA standards } & \multicolumn{4}{|c|}{ EU standards } \\
\hline Name & Engine power & $\mathrm{CO}$ & $\mathrm{NO}_{x}$ & Name & Engine power & $\mathrm{CO}$ & $\mathrm{NO}_{x}$ \\
\hline Tier 2 & $130-560 \mathrm{~kW}$ & 3.5 & 6.4 & Stage II & $130-560 \mathrm{~kW}$ & 3.5 & 6 \\
\hline \multirow{2}{*}{ Tier 3} & \multirow{2}{*}{$130-560 \mathrm{~kW}$} & \multirow{2}{*}{3.5} & \multirow{2}{*}{4} & Stage IIIA & $130-560 \mathrm{~kW}$ & 3.5 & 4 \\
\hline & & & & Stage IIIB & $130-560 \mathrm{~kW}$ & 3.5 & 2 \\
\hline Tier 4 & $130-560 \mathrm{~kW}$ & 3.5 & 0.4 & Stage IV & $130-560 \mathrm{~kW}$ & 3.5 & 0.4 \\
\hline
\end{tabular}

154, 335 and 344 of the Federal Rules and Regulations Safety Rules for Mining and Processing of Solid Minerals [12], stipulating that the required volume of air for dilution of the exhaust gas components is to be determined by carbon monoxide and nitrogen oxide components, as well as the minimum permissible air oxygen content of $20 \%$.

Another issue is the present-day quality of the diesel fuel and the impact of its composition on the concentration of the exhaust gas components.

At present, there are two national standards (GOST) for EVRO diesel fuel grades for diesel engines applicable in Russia:

- GOST R 52368-2005 (EN 590:2009) Diesel fuel EVRO. Specifications. [13] (National Standard)

- GOST 32511-2013 (EN 590:2009) Diesel EVRO. Specifications. [14] (Interstate Standard).

These standards provide requirements for the diesel fuel composition, including such properties as cetane number, fuel density, content of sulphur ( $\mathrm{mg} / \mathrm{kg}$ ) and polycyclic aromatic hydrocarbons (mass \%) in fuel, and other indicators for summer, winter and inter-season diesel fuel grades.

However, the content of sulphur and polycyclic aromatic hydrocarbons does not affect the content of carbon monoxide and nitrogen oxides in the exhaust gases of internal combustion engine vehicles. The emissions of carbon oxides and nitrogen oxides in exhaust gases are controlled by after-treatment and depend mainly on an engine's emission class [15-20].

Internal combustion engine toxicity standards for off-road vehicles are determined in accordance with the following standards:

1. Stage - certification standard adopted in the European Union (EU) countries. It was first implemented by EU Directive 97/68/EC [21] in 1997, further revised in 2002 by Directive 2002/88/EC [22], setting emission limits for Stage I and Stage II emission standards. EU Directive 2004/26/EC [23] introduced emission limits for
Stage IIIA, Stage IIIB and Stage IV emission standards in 2004.

2. EPA Tier - certification standard adopted in the USA. It was first introduced by the Code of Federal Regulations [24] in 1999, setting emission limits for Tier 1 , Tier 2 and Tier 3 emission regulations. In 2012, the Code of Federal Regulations [25] was supplemented with emission limits for Tier 4 emission regulations.

These standards stipulate a limit of emissions for off-road vehicles by nitrogen oxides and carbon monoxide. The emission standards are given in Table 2.

Therefore, the procedure for determining the air quantity required to dilute exhaust gas components should provide determination variability subject to specific conditions to ensure safe working conditions.

\section{Determination of Air Quantity \\ Requirement for Operating Areas of Internal Combustion Engine \\ Vehicles in Underground Mines}

Based on the previously mentioned, the following approaches are proposed to define the air quantity required for the operating areas of internal combustion engine vehicles.

1. By exhaust combustion gas parameters. The amount of harmful substances in the exhaust combustion gases can be determined through direct measurements in operating modes of the internal combustion engine vehicles. Based on these data, the airflow rate required to dilute the emitted harmful gases to the maximum permissible concentrations should be determined.

When designing mining enterprises, this approach can be used during technical upgrades or reconstructions of mines, when it is planned to engage some portion of the machinery fleet currently in operation. A long-term monitoring will help to identify the level of the harmful 
exhaust gas emissions, which will allow to define the required amount of air in the project.

However, this approach has its limitations. During machinery operations, the engine performance can vary entailing the increase in the emission of harmful and hazardous substances. In this case, the supply of previously calculated air quantities may be insufficient to dilute these substances. A comprehensive approach is essential to avoid the possibility of such a situation by introducing a limit on emissions that is higher than the actual level. For example, the emission standard can be adopted from the most contaminating vehicle in use. In addition, the quantity of harmful substances in the exhaust gases shall be monitored during operation by direct measurements in accordance with the requirements of paragraph 343 of the Safety Rules for Mining and Processing of Solid Minerals [12]. If the established emission limit is exceeded, such vehicle shall be withdrawn from operations for maintenance or repair. In this way, the operating company is encouraged to perform timely maintenance and renewal of the internal combustion engine machinery fleet.

On the other hand, exhaust-gas measurements for new vehicles with internal combustion engines, which are in a perfect technical condition, may indicate a low level of harmful substance emissions in exhaust gases. Furthermore, there is a risk of insufficient air supply in case of errors in the routine measurements of harmful combustion gas components of internal combustion engines. In this case, it would be advisable to reduce the risks by recalculating the level of harmful emissions to a conditional air supply limit per unit of the engine power and introducing a minimum airflow limiting rate.

The case of one of the underground mines can illustrate the situation described above. Based on the measurement statistics of the exhaust gas parameters, the required air supply limit per $1 \mathrm{HP}$ of the internal combustion engine vehicles was determined. The standard air supply rate of $1.5 \mathrm{~m}^{3} / \mathrm{min}$ per $1 \mathrm{HP}$ was adopted as the minimum value. The air supply below the value determined as per this limit is not allowed, even for those types of internal combustion engine vehicles with an air supply value of $0.8-1 \mathrm{~m}^{3} / \mathrm{min}$ per $1 \mathrm{HP}$, calculated based on the harmful substances emission level. An additional permissible emission standard providing for the air supply rate of $3 \mathrm{~m}^{3} / \mathrm{min}$ per $1 \mathrm{HP}$, determined with reference to the required airflow rate, was also introduced, allowing the vehicle operation.

2 . By the engine emission class. The level of contaminants in the exhaust combustion gases of the procured vehicles cannot be determined directly under working conditions for newly designed mines. In this case, it is advisable to apply the maximum possible level of emissions that is guaranteed by the equipment manufacturer through the engine certification as per its emission class.

3. By oxygen content in the operating area of internal combustion engine vehicles. The issue of rating the oxygen content in the operating areas of the internal combustion engine vehicles should be also considered, as it is related to emissions of harmful substances. The quantity of air required to ensure the standard-compliant oxygen content is determined based on the specific fuel consumption rate of the internal combustion engine vehicles.

Thus, the quantity of fresh air supplied to the workings in the operating areas where the internal combustion engine vehicles are on a continuous or intermittent duty $\left(Q_{\mathrm{CG}}\right)$ shall be no less than required for static dilution of the main exhaust gas components (carbon monoxide, nitrogen dioxide calculated as $\mathrm{NO}_{2}$ ) to the maximum permissible concentrations or for ensuring the standardcompliant oxygen content, and is defined by the expression given below:

$$
Q_{\mathrm{CG}}, \mathrm{m}^{3} / \mathrm{c}=K_{\mathrm{s}} \cdot \Sigma Q_{\mathrm{ICE}},
$$

where $K_{\mathrm{S}}$ is the simultaneity factor of operation of the internal combustion engine vehicles in a separate working, $K_{\mathrm{S}}=1 ; 0.9 ; 0.85$ at the simultaneous operation of one, two, three and more vehicles, respectively; $Q_{\text {ICE }}$ is the air quantity required to ventilate each vehicle from harmful factors of internal combustion engines, $\mathrm{m}^{3} / \mathrm{s}$ [26].

$Q_{\text {ICE }}$ is determined separately for each specified exhaust gas component (carbon monoxide, nitrogen dioxide calculated as $\mathrm{NO}_{2}$ ) at the maximum possible engine speed and for oxygen. The highest obtained value of the airflow rate is taken as the required air quantity.

\section{Determining the Required Air Quantity for Operating Areas of Internal Combustion Engine Vehicles}

A more detailed determination principle is shown on the examples of some mining equipment 
used at producing mines. The equipment specifications given in Table 3 were used for the calculations.

Table 3

Equipment specifications

\begin{tabular}{lcccc}
\hline \multicolumn{1}{c}{ Model } & $\begin{array}{c}\text { Toxicity } \\
\text { Class }\end{array}$ & $\begin{array}{c}\text { Engine } \\
\text { capacity, 1 }\end{array}$ & $\begin{array}{c}\text { Crankshaft } \\
\text { speed, rpm }\end{array}$ & $\begin{array}{c}\text { Power, } \\
\text { kW }\end{array}$ \\
\hline ST-14 & Tier 3B & 10.8 & 2,100 & 224 \\
\hline Cat R1700 & Tier 3B & 11.1 & 2,100 & 242 \\
\hline MT-42 & Tier 4 & 15.0 & 1,800 & 391 \\
\hline
\end{tabular}

\section{Principles of the Required Airflow Determination by Exhaust Combustion Gas Parameters}

To determine the required airflow based on the factor of an independent emission of the harmful exhaust gas components of the internal combustion engine vehicles in operation, the following expression for defining the required fresh airflow rate is used to dilute the harmful exhaust gas components to permissible values:

$$
Q_{\mathrm{ICE}}, \mathrm{m}^{3} / \mathrm{c}=\frac{C_{\text {exh }}}{C_{\mathrm{mpc}}} \cdot g_{\text {exh }},
$$

where $C_{\text {exh }}$ is the concentration of the exhaust gas toxic components (carbon monoxide, nitrogen dioxide calculated as $\mathrm{NO}_{2}$ ), vol. \%; $C_{\text {mpc }}$ is the maximum permissible concentration for the corresponding component, the volume percent for $\mathrm{CO}$ is $0.0017 \%$, and $0.00026 \%$ for NOx; $g_{\text {exh }}$ is the quantity of the exhaust gases, $\mathrm{m}^{3} / \mathrm{s}$.

The quantity of the exhaust gases $g_{\text {exh }}$ is determined by on-site measurements with the use of a flowmeter in modes stipulated by Paragraph 344 of the Federal Rules and Regulation (FNiP) [12]. When it is impossible to have a direct measurement of the exhaust gas flow, $g_{\text {exh }}$ is calculated from the data in the vehicle technical data sheet using the expression for a four-stroke engine given below [27]:

$$
g_{\text {exh }}, \mathrm{m}^{3} / \mathrm{c}=k \frac{V n}{2},
$$

where $k$ is the factor correcting for the pressure excess; $V$ is the total cylinder capacity, $\mathrm{m}^{3} ; n$ is the crankshaft speed, rps (full speed as per the engine specification).
The results of calculating the required air quantity using the above method are shown in Table 4. Air sampling data of the mining equipment at one of the operating mines were used for calculations.

The use of the above formula is reasonable, as it takes into account the technical reserve, since the engine does not always run at full speed, and the average amount of the exhaust gas emissions is less than the maximum value calculated by the expression. This expression is applicable for both atmospheric and turbocharged engines, as confirmed by regulatory documents $[28,29]$ and scientific literature [30-39].

The measured volume concentration of the exhaust gas does not require recalculations when the exhaust gas flow temperature changes, according to the expression of the gas component volume concentration given below:

$$
C_{i}, \mathrm{~m}^{3} / \mathrm{m}^{3}=\frac{V_{i}(P, T)}{V(P, T)},
$$

where $V_{i}(P, T)$ is the volume occupied by the $i$-th gas component; $P$ is the gas pressure, $\mathrm{Pa} ; T$ is the temperature, $\mathrm{K} ; V(P, T)$ is the total gas volume equal to the sum of volumes of all the components composing the gas.

Table 4

Air quantity determination results by the exhaust gas components

\begin{tabular}{lcccc}
\hline \multirow{2}{*}{ Model } & \multicolumn{2}{c}{$\begin{array}{c}\text { Air sampling, } \\
\text { volume } \%\end{array}$} & \multicolumn{2}{c}{$\begin{array}{c}\text { Required air } \\
\text { quantity, } \mathrm{m}^{3} / \mathrm{s}\end{array}$} \\
\cline { 2 - 5 } & $\mathrm{CO}$ & $\mathrm{NO}_{x}$ & $\mathrm{CO}$ & $\mathrm{NO}_{x}$ \\
\hline ST-14 & 0.0106 & 0.0052 & 1.2 & 3.8 \\
\hline ST-14 & 0.0132 & 0.0104 & 1.5 & 7.6 \\
\hline Cat R1700 & 0.0061 & 0.0052 & 0.7 & 3.9 \\
\hline Cat R1700 & 0.0106 & 0.0026 & 1.2 & 1.9 \\
\hline MT-42 & 0.01 & 0.0002 & 1.3 & 0.2 \\
\hline MT-42 & 0.01 & 0.01 & 1.3 & 8.7 \\
\hline
\end{tabular}

With the change in atmospheric conditions (pressure and temperature), the parameters of all gas components change accordingly. Therefore, the volume occupied by a single gas component varies in proportion to the total volume of the gas. In such a case, the volume concentration does not change with the changes in atmospheric conditions.

If there are no required baseline data on measured harmful substance concentrations, the data sheet specifications of the engine's hazardous 
emissions are used for calculations. The expression (2) for such case is given below:

$$
Q_{\mathrm{ICE}}, \mathrm{m}^{3} / \mathrm{min}=k \cdot \frac{C_{\mathrm{exh}}}{C_{\mathrm{mpc}} \cdot \rho} \cdot N \text {, }
$$

where $k$ is the conversion factor, converting between hours and minutes, and between percentage and unit fractions; Cexh is the specific quantity of emissions for the corresponding component, $\mathrm{kg} / \mathrm{kWh} ; C_{\mathrm{mpc}}$ is the maximum permissible concentration for the corresponding component, vol. \%; $\rho$ is the density of the corresponding gas, $\mathrm{kg} / \mathrm{m}^{3}$, taken as equal to $1.15 \mathrm{~kg} / \mathrm{m}^{3}$ for $\mathrm{CO}$, and $2.1 \mathrm{~kg} / \mathrm{m}^{3}$ for NOx; $N$ is the engine power, $\mathrm{kW}$.

\section{Air Quantity Determination by Engine Emission Classes}

When designing new mines, sites or horizons, the procurement of new internal combustion engine equipment is considered. In this case, the air quantity requirement cannot be determined based on the actual harmful exhaust gas emissions. However, the equipment procured for mining operations is subject to mandatory engine toxicity certification, and the manufacturer confirms the engine's compliance to a certain emission class.

When a project provides for the procurement of the internal combustion engine vehicles, the airflow is calculated by the exhaust gas components based on the engine's emission class according to the emission limits given in Table 2 .

The airflow rate for the internal combustion engine vehicles is defined by the expression given below (5):

$$
Q_{\mathrm{ICE}}, \mathrm{m}^{3} / \mathrm{c}=\frac{N Y}{60},
$$

where $N$ is the engine power, HP; $Y$ is the specific airflow rate per $1 \mathrm{HP}$ of the engine power in accordance with the diesel engine toxicity standards, which are defined from Tables 5 and 6.

\section{Air Quantity Determination by Oxygen Content}

According to paragraph 335 of FNiP [12], the quantity of air supplied to the operating areas of the internal combustion engine vehicles is to ensure a minimum oxygen content in the air of the operating areas of the internal combustion engine vehicles of $20 \%$ by volume.

Therefore, the air quantity shall also be determined based on the oxygen content factor in the operating areas of such vehicles.

Table 5

Specific airflow rate per unit

of the internal combustion engine power according to toxicity standards

\begin{tabular}{lccc}
\hline \multirow{2}{*}{ Standard } & Engine & \multicolumn{2}{c}{$Y, \mathrm{~m}^{3} / \mathrm{min}$ per 1 HP } \\
\cline { 3 - 4 } & power, HP & $\mathrm{CO}$ & $\mathrm{NO}_{X}$ \\
\hline Tier 2/Stage II & $177-760$ & 2.24 & 13.74 \\
\hline Tier 3/Stage IIIA & $177-760$ & 2.24 & 9.16 \\
\hline Stage IIIB & $177-760$ & 2.24 & 4.58 \\
\hline Tier 4/Stage IV & $177-760$ & 2.24 & 0.92 \\
\hline
\end{tabular}

Table 6

Air quantity determination results by toxicity standards

\begin{tabular}{lcccc}
\hline \multirow{2}{*}{ Model } & Standard & \multirow{2}{*}{$\begin{array}{c}\text { Engine } \\
\text { power, HP }\end{array}$} & \multicolumn{2}{c}{$\begin{array}{c}\text { Required air } \\
\text { quantity, } \mathrm{m}^{3} / \mathrm{s}\end{array}$} \\
\cline { 4 - 5 } & & & $\mathrm{CO}$ & $\mathrm{NO}_{x}$ \\
\hline ST-14 & Stage IIIB & 304.5 & 11.4 & 23.2 \\
\hline Cat R1700 & Stage IIIB & 329.0 & 12.3 & 25.1 \\
\hline MT-42 & Tier 4 & 531.6 & 19.8 & 8.2 \\
\hline
\end{tabular}

The oxygen content is determined based on the expression describing the chemical reaction of hydrocarbon fuel oxidation. According to this expression, there is a stoichiometric level of oxygen for each fuel grade, i.e. the amount needed for the complete fuel combustion $\left(L_{0}\right)$.

The fuel contains $\mathrm{C} / 100 \mathrm{~kg}$ of carbon, $\mathrm{H} / 100 \mathrm{~kg}$ of hydrogen, $\mathrm{S} / 100 \mathrm{~kg}$ of volatile sulphur and $\mathrm{O} / 100 \mathrm{~kg}$ of oxygen. Therefore, the stoichiometric amount of oxygen $\left(L_{0}\right)$ is determined subject to the complete combustion of all fuel by stoichiometric equations, as given below [17-20, 40]:

$$
L_{0}, \mathrm{~kg}=\frac{2,67 \mathrm{C}+8 \mathrm{H}+\mathrm{S}+\mathrm{O}}{100} .
$$

Therefore, the stoichiometric amount of oxygen is determined for each fuel grade individually and depends on its chemical composition. The elemental composition of diesel fuel grades is given in Table 7 [17-20, 41].

Based on the elemental composition data of diesel fuel grades, the content of individual components in fuels varies within a narrow range and should be considered as relatively constant. In 
this case, the stoichiometric amount of oxygen can also be considered a constant number. The average of mass fraction of air oxygen is taken as equal to 0.232 . The combustion of 1 kilogram of fuel requires the quantity of air that is called the stoichiometric amount of air $L_{0}$. According to [17-20, 42], the stoichiometric amount of air $L_{0}$ is $14.42 \mathrm{~kg}$ for the summer-grade diesel fuel.

The above conditions present an ideal case. However, under real conditions the mixing of fuel and air in the engine working cylinder is different. Commonly, the engine runs with air excess or deficiency. For this reason, to determine the required air supply to the engine, $\alpha$ value, referred to as the air excess factor, which shows the ratio of the actual quantity of air supplied to the engine to the theoretical amount, is used. The $\alpha$ value is always greater than 1 , and for diesel engines it ranges from 1.3 to 2.2 depending on the design features [15-19, 43-45]. It should be noted that the same amount of oxygen is used in the fuel combustion, and the oxygen not used in the process is emitted into the atmosphere as part of the exhaust gases. The amount of residual oxygen is defined by the expression given below:

$$
l_{\text {кисл }}, \mathrm{kg}=0,21(\alpha-1) \cdot l_{0} .
$$

Therefore, for the internal combustion engine vehicle, the airflow rate $\left(Q_{0}\right)$ required for the engine operation is defined by the expression given below:

$$
Q_{0}, \mathrm{~m}^{3} / \mathrm{c}=\frac{21 \cdot L_{0} \cdot N \cdot q}{3600 \cdot \rho \cdot K_{0}},
$$

where $N$ is the engine power rating, $\mathrm{kW} ; q$ is the specific fuel consumption at rated power, $\mathrm{kg} / \mathrm{kWh}$; $\rho$ is the air density (taken as equal to $1.23 \mathrm{~kg} / \mathrm{m}^{3}$ ); $K_{0}$ is the air oxygen, vol. \%.

Airflow rate $Q_{0}$ is the amount of air, at which all oxygen contained in the air, is used for fuel oxidation.

Then, the airflow rate required for the combustion process, where the minimum final oxygen air content after fuel combustion is $20 \%$ by volume, is defined by the expression given below:

$$
Q_{\mathrm{ICE}}, \mathrm{m}^{3} / \mathrm{c}=\frac{21 \cdot L_{0} \cdot N \cdot q}{3600 \cdot \rho \cdot\left(K_{0}-20\right)},
$$

where $N$ is the engine power rating, $\mathrm{kW} ; L_{0}$ is the quantity of air required for the combustion of 1 kilogram of fuel (equals to $14.42 \mathrm{~kg}$ ); $q$ is the specific fuel consumption at rated power, $\mathrm{kg} / \mathrm{kWh} ; \rho$ is the air density (taken as equal to $1.23 \mathrm{~kg} / \mathrm{m}^{3}$ ); $K_{0}$ is the oxygen content in the air supplied for ventilation, vol. \%, assumed as equal to the oxygen content in the atmosphere, as the mines use a separate ventilation of the operating areas (Table 8).

Table 7

Elemental composition of diesel fuel

\begin{tabular}{lc}
\hline \multicolumn{1}{c}{ Chemical element } & Component's proportion, mass $\%$ \\
\hline Carbon & $85.5-87.0$ \\
\hline Hydrogen & $12.8-14.0$ \\
\hline Volatile sulphur & $0.2-1.0$ \\
\hline Oxygen & 0 \\
\hline
\end{tabular}

Table 8

Air quantity determination results by oxygen content

\begin{tabular}{lc}
\hline \multicolumn{1}{c}{ Model } & Required air quantity, $\mathrm{m}^{3} / \mathrm{s}$ \\
\hline ST-14 & 4.1 \\
\hline Cat R1700 & 4.4 \\
\hline MT-42 & 7.8 \\
\hline
\end{tabular}

Table 9

\begin{tabular}{|c|c|c|c|c|c|c|c|}
\hline \multirow{3}{*}{ Model } & \multicolumn{7}{|c|}{ Air quantity requirement, $\mathrm{m}^{3} / \mathrm{s}$} \\
\hline & \multicolumn{2}{|c|}{ Samples } & \multicolumn{2}{|c|}{$\begin{array}{l}\text { Toxicity } \\
\text { standard }\end{array}$} & \multirow[t]{2}{*}{$\mathrm{O}_{2}$} & \multirow[t]{2}{*}{ Max } & \multirow{2}{*}{$\begin{array}{c}Y, \\
\mathrm{~m}^{3} / \mathrm{min} \\
\text { per } 1 \mathrm{HP}\end{array}$} \\
\hline & $\mathrm{CO}$ & $\mathrm{NO}_{x}$ & $\mathrm{CO}$ & $\mathrm{NO}_{x}$ & & & \\
\hline$\overline{\text { ST-14 }}$ & 1.2 & 3.8 & 11.4 & 23.2 & 4.1 & 4.1 & 0.8 \\
\hline ST-14 & 1.5 & 7.6 & 11.4 & 23.2 & 4.1 & 7.6 & 1.5 \\
\hline Cat R1700 & 0.7 & 3.9 & 12.3 & 25.1 & 4.4 & 4.4 & 0.8 \\
\hline Cat R1700 & 1.2 & 1.9 & 12.3 & 25.1 & 4.4 & 4.4 & 0.8 \\
\hline MT-42 & 1.3 & 0.2 & 19.8 & 8.2 & 7.8 & 7.8 & 0.9 \\
\hline MT-42 & 1.3 & 8.7 & 19.8 & 8.2 & 7.8 & 8.7 & 1 \\
\hline
\end{tabular}

Air quantity determination results by toxicity standards

Calculations based on the above procedure allow us to determine the amount of air required to dilute the exhaust gas components. A comparison of the calculated values of the components is given in Table 9.

The component with the highest calculated value should be used in the final calculation. The proposed procedure for the air quantity requirement determination provides variability of the approach. Depending on specific situations and the availability of the required baseline data, the air quantity required for dilution of the exhaust gas carbon monoxide and nitrogen oxides can be determined based on on-site sampling, 
operating vehicle data sheet or engine toxicity standards. In the case in question, the exhaust gas samples were taken from vehicles in operation, and the determination by engine toxicity standards was performed as an example. In the final comparison, the results of the calculation based on the diesel engine toxicity standards should not be taken into account due to the availability of test measurements of the exhaust gas components for a number of similar vehicles. The calculations based on engine toxicity standards should be performed at the design stage for new sites, horizons or mines in case new vehicles are being procured, where on-site exhaust gas sampling data or engine data sheet specifications are not available.

\section{Conclusions}

By using the above calculations as an example, it can be concluded based on the exhaust gas sampling data from the vehicles in service that the actual fresh air supply rate is in fact lower than the toxicity standard requirements. This may be partly due to the technological process of mining equipment, its operating cycle differing from that of an engine certified to EPA Tier and Stage standards.

Modern machinery with good exhaust gas after-treatment units ensures reduction of the exhaust gas component concentrations to the values stipulated by the applied overseas Stage and EPA Tier standards. However, the actual mining equipment operating conditions impact real emissions of hazardous and poisonous exhaust gas components, which affects the determination of the air quantity required for their dilution. As evidenced in practice, many mining enterprises validate the fresh air supply rate for the exhaust gas components dilution ranging from 1.5 to $3.0 \mathrm{~m}^{3} / \mathrm{min}$ per $1 \mathrm{HP}$ of the engine power in the Russian Federal Service for Environmental, Technological, and Nuclear Supervision.

The application of the above methods to determine the air quantity required for the exhaust gas components dilution will make it possible for mining companies to define the actual fresh air supply requirement when operating machinery powered by the internal combustion engines, and to identify the most suitable equipment for design companies subject to the specific conditions of each deposit, which will allow us to enhance the effectiveness of the ventilation equipment resources.

\section{References}

1. PB 06-111-95 Edinye pravila bezopasnosti pri razrabotke rudnykh, nerudnykh i rossypnykh mestorozhdenii poleznykh iskopaemykh podzemnym sposobom: utv. Postanovleniem Gosgortekhnadzorom Rossii ot 23.01.1995 № 4 [PB 06-111-95 Unified safety rules for the development of ore, nonmetallic and placer deposits of minerals by the underground method: approved. Resolution of the Gosgortekhnadzor of Russia dated January 23, 1995 No. 4]. Moscow, 1995.

2. VNTP 13-2-93 Normy tekhnologicheskogo proektirovaniia gornodobyvaiushchikh predpriiatii metallurgii $\mathrm{s}$ podzemnym sposobom razrabotki: utv. Komitetom Rossiiskoi Federatsii po metallurgii (protokol ot 27.01.1993, no. 1) po soglasovaniiu s Gosgortekhnadzorom RF (protokol ot 13.12. 1992, no. 4) [VNTP 13-2-93 Standards for technological design of mining metallurgy enterprises with underground mining method: approved. The Committee of the Russian Federation for Metallurgy (protocol of January 27, 1993, no. 1) in agreement with the Gosgortekhnadzor of the Russian Federation (protocol of December 13, 1992, no. 4)]. Moscow, 1993.

3. Stinnette J. D., De Souza E. Establishing total airflow requirements for underground metal/non metal mines with tier IV diesel equipment. 23rd World Mining Congress and Expo, 2013.

4. Chang P., Xu G. Review of Diesel Particulate Matter Control Methods in Underground Mines. Proceedings of the 11th International Mine Ventilation Congress. Springer, Singapore, 2019, pp. 461-470. DOI: 10.1007/978-981-13-1420-9_39

5. McGinn S. Controlling diesel emissions in underground mining within an evolving regulatory structure in Canada and the United States of America, 2016.

6. Zhang H. A framework to develop a hybrid methodology for modeling of diesel particulate matter concentration in underground mine ventilation systems: dis. thesis. Laurentian University of Sudbury, 2019.

7. Reger R. et al. Coal miners exposed to diesel exhaust emissions. The Annals of Occupational Hygiene, 1982, vol. 26, iss. 8, pp. 799-815. DOI: 10.1093/annhyg/26.8.799

8. Sassykova L.R. et al. The main components of vehicle exhaust gases and their effective catalytic neutralization. Oriental Journal of Chemistry, 2019, vol. 35, no. 1, pp. 110-127. DOI: $10.13005 /$ ojc/350112

9. Mischler S.E., Colinet J.F. Controlling and monitoring diesel emissions in underground mines in the United States, 2009.

10. Halim A. Ventilation requirements for diesel equipment in underground mines-Are we using the correct values. 16th North American Mine Ventilation Symposium, Golden, Colorado, 2017, pp. 1-7.

11. Villa T.F. Development of an unmanned aerial vehicle (UAV) system for in-situ characterization of combustion source emissions. Queensland University of Technology, 2017. DOI: 10.5204/thesis.eprints.114062

12. Pravila bezopasnosti pri vedenii gornykh rabot $i$ pererabotke tverdykh poleznykh iskopaemykh: Federal'nye normy $\mathrm{i}$ pravila $\mathrm{v}$ oblasti promyshlennoi bezopasnosti, utv. prikazom Rostekhnadzora ot 11.12.2013, no. 599 (s izmeneniiami na 21 noiabria 2018 goda) [Safety rules for mining and processing of solid minerals: Federal norms and rules in the field of industrial safety, approved by order of Rostekhnadzor dated December 11, 2013, no. 599 (as amended on November 21, 2018)]. Moscow, 2018.

13. GOST R 52368-2005 (EN 590:2009) Toplivo dizel'noe EVRO. Tekhnicheskie usloviia [GOST R 52368-2005 (EN 590: 2009) Diesel fuel EURO. Specification]. Moscow, 2005.

14. GOST 32511-2013 (EN 590:2009) Toplivo dizel'noe EVRO. Tekhnicheskie usloviia [GOST 32511-2013 (EN 590: 2009) Diesel fuel EURO. Specifications]. Moscow, 2013. 
15. GOST 305-2013 Toplivo dizel'noe. Tekhnicheskie usloviia (Pereizdanie) [GOST 305-2013 Diesel fuel. Specifications (Reissue)]. Moscow, 2013.

16. Khodiakov A.A., Khlopkov S.V., Bernatskii V.V. Fizikokhimicheskie svoistva dizel'nogo topliva standarta "Evro" [Physical and chemical properties of diesel fuel standard of Euro]. Zhurnal avtomobil'nykh inzhenerov, 2017, no. 1, pp. 40-43.

17. Lukanin V.N., Morozov K.A., Khachiian A.S. et al. Dvigateli vnutrennego sgoraniia. Kniga 1 . Teoriia rabochikh protsessov [Internal combustion engines. Book 1. Workflow Theory]. Ed. V.N. Lukanina. 2nd ed. Moscow: Vysshaia shkola, 2005, book $1,479 \mathrm{p}$.

18. Orlin A.S. Dvigateli vnutrennego sgoraniia. Ustroistvo i rabota porshnevykh i kombinirovannykh dvigatelei [Internal combustion engines. Design and operation of piston and combined engines]. Eds. A.S. Orlina, M.G. Kruglova. 4nd ed. Moscow: Mashinostroenie, 1990, $289 \mathrm{p}$

19. Kruglov M.G., Mednov A.A. Gazovaia dinamika kombinirovannykh dvigatelei vnutrennego sgoraniia [Gas dynamics of combined combustion engines]. Moscow: Mashinostroenie, 1998, 360 p.

20. Khachiian A.S., Morozov K.A., Lukanin V.N. et al. Dvigateli vnutrennego sgoraniia [Internal combustion engines]. Ed. V.N. Lukanin, 2nd ed. Moscow: Vysshaia shkola, 1985, 311 p.

21. Direktiva 97/68/ES Evropeiskogo Parlamenta i Soveta ot 16 dekabria $1997 \mathrm{~g}$. o sblizhenii zakonov gosudarstv-chlenov, kasaiushchikhsia priniatiia mer protiv vybrosov gazoobraznykh zagriaznitelei i tverdykh chastits iz dvigatelei $s$ vnutrennim sgoraniem dvigatelei dlia ustanovki na vnedorozhnoi mobil'noi tekhnike [Directive 97/68/EC of the European Parliament and of the Council of 16 December 1997 on the approximation of the laws of the Member States relating to measures against the emission of gaseous and particulate pollutants from internal combustion engines to be installed in non-road mobile machinery], available at: https://www.ecolex.org/details/legislation/directive-97 68ec-of-theeuropean-parliament-and-of-the-council-on-the-approximation-of-thelaws-of-the-member-states-re-lating-to-measures-against-the-emissionof-gaseous-and-particulate-pollutants-from-internal-combustion-engines-to-be-installed-in-non-road-mobile-machinery-lex-faoc 038124/ (accessed 10 December 2019).

22. Direktiva 2002/88/ES Evropeiskogo Parlamenta i Soveta ot 9 dekabria 2002 g. ob izmenenii Direktivy 97/68/ES o sblizhenii zakonov gosudarstv-chlenov, kasaiushchikhsia priniatiia mer protiv vybrosov gazoobraznykh zagriaznitelei i tverdykh chastits iz dvigatelei s vnutrennim sgoraniem dvigatelei dlia ustanovki na vnedorozhnoi mobil'noi tekhnike) [Directive 2002/88/EC of the European Parliament and of the Council of 9 December 2002 amending Directive 97/68/EC on the approximation of the laws of the Member States relating to measures against the emission of gaseous and particulate pollutants from internal combustion engines to be installed in non-road mobile machinery], available at: https:// www.eea.europa.eu/policy-documents/directive-2002-88-ec (accessed 10 December 2019).

23. Direktiva 2004/26/ES Evropeiskogo Parlamenta i Soveta ot 21 aprelia 2004 g. ob izmenenii Direktivy 97/68/ES o sblizhenii zakonov gosudarstv-chlenov, kasaiushchikhsia priniatiia mer protiv vybrosov gazoobraznykh zagriaznitelei i tverdykh chastits iz dvigatelei s vnutrennim sgoraniem dvigatelei dlia ustanovki na vnedorozhnoi mobil'noi tekhnike) [Directive 2004/ 26/EC of the European Parliament and of the Council of 21 April 2004 amending Directive 97/68/EC on the approximation of the laws of the Member States relating to measures against the emission of gaseous and particulate pollutants from internal combustion engines to be installed in non-road mobile machinery], available at: https://www.icqc.eu/ userfiles/File/directive $\% 202004 \% 2022 \% 20 \mathrm{EC} \% 20$ measuring\%20i nstruments.pdf (accessed 10 December 2020).

24. Svod Federal'nykh normativnykh aktov, tom 40, chast' 89 . Kontrol' vybrosov novykh i ispol'zuemykh vnedorozhnykh mashin s dvigateliami vnutrennego sgoraniia [Code of Federal Regulations, 40. Part 89. 1999. CONTROL OF EMISSIONS FROM NEW AND IN-USE NONROAD COMPRESSION-IGNITION ENGINES], available at: https://www.law.cornell.edu/cfr/ text/40/part-89 (accessed 10 December 2020)

25. Svod Federal'nykh normativnykh aktov, tom 40, chast' 1039. Kontrol' vybrosov novykh i ispol'zuemykh vnedorozhnykh mashin s dvigateliami vnutrennego sgoraniia [Code of Federal Regulations, 40. Part 1039. 2012. CONTROL OF EMISSIONS FROM NEW AND IN-USE NONROAD COMPRESSION-IGNITION ENGINES], available at: https://www. govregs.com/regulations/40/1039 (accessed 10 December 2020).

26. Vremennaia instruktsiia po raschetu kolichestva vozdukha, neobkhodimogo dlia provetrivaniia rudnykh shakht. Moscow, 1983.

27. Rudnichnaia ventiliatsiia: spravochnik [Mine ventilation: a handbook]. Ed. professor K.Z. Ushakov. Moscow: Nedra, 1988.

28. GOST 17.2.2.01-84. Dizeli avtomobil'nye. Dymnost' otrabotavshikh gazov. Normy i metody izmerenii [GOST 17.2.2.01-84. Diesels are automobile. Smoke in exhaust gases. Measurement standards and methods]. Moscow, 1984.

29. GOST 31967-2012 Dvigateli vnutrennego sgoraniia porshnevye. Vybrosy vrednykh veshchestv s otrabotavshimi gazami. Normy i metody opredeleniia (s Izmeneniem № 1) [GOST 31967-2012 Reciprocating internal combustion engines. Emissions of harmful substances with exhaust gases. Norms and methods of determination (with Amendment No. 1)]. Moscow, 2012.

30. Gorbunov V.V., Patrakhal'tsev N.N. Toksichnost' dvigatelei vnutrennego sgoraniia [Study of the toxicity of exhaust gases of a diesel engine with intermediate cooling of charging air when operating on natural gas]. Moscow: Rossiiskii universitet druzhby narodov, 1998, $214 \mathrm{p}$.

31. Likhanov V.A., Lopatin O.P. Issledovanie toksichnosti otrabotavshikh gazov dizelia s promezhutochnym okhlazhdeniem nadduvochnogo vozdukha pri rabote na prirodnom gaze [Study of the toxicity of exhaust gases of a diesel engine with intermediate cooling of charging air when operating on natural gas]. Stroitel'nye i dorozhnye mashiny, 2016, no. 9, pp. 30-34.

32. Golokhvast K.S., Chernyshev V.V., Ugai S.M. Vybrosy avtotransporta i ekologiia cheloveka (obzor literatury) [Emissions from vehicles and human ecology (literature review)]. Ekologiia cheloveka, 2016, no. 1.

33. Kovalevskii V.V., Frolov A.V. Otsenka ekologicheskoi bezopasnosti avtomobil'nykh dizelei termokhimicheskirezistivnym metodom [The estimation of motor diesel engine ecological safety by thermochemical-photoconductive method]. Ekologicheskie sistemy i pribory, 2007, no. 1, pp. 1-6.

34. Shapko V.F. et al. Ekologicheskie pokazateli dizel'nykh dvigatelei s raznymi usloviiami smeseobrazovaniia pri rabote na biodizel'nom toplive [Environmental performance of diesel engines with different mixing conditions when operating on biodiesel fuel]. Novye materialy i tekhnologii v mashinostroenii, 2011, no. 13, pp. 150-153.

35. Chernyshev V.V. et al. Issledovanie kachestvennogo sostava tverdykh chastits vykhlopov DVS avtomobilei bez probega [A qualitative study composition of particulate matter emissions engine vehicles without mileage]. Gornyi informatsionnoanaliticheskii biulleten' (nauchno-tekhnicheskii zhurnal), 2014, no. S4-11, pp. 160-167.

36. Kamaldinov V.G., Markov V.A., Dragunov G.D. Otsenka pokazatelei rabochego tsikla HCCI-dvigatelia s nadduvom pri razlichnykh chastotakh vrashcheniia kolenchatogo vala i nagruzkakh [Evaluation of duty cycle parameters of an HCCIsupercharged engine at various loads and rotational speeds of the crankshaft]. Izvestiia vysshikh uchebnykh zavedenii. Mashinostroenie, 2014, no. 6 (651), pp. 25-34.

37. Kuleshov V.K., Brazovskii V.V., Baranov V.A. Kontrol' parametrov produktov sgoraniia $\mathrm{v}$ fil'tratsionnykh ustanovkakh 
[Control of combustion product parameters in filtration devices]. Izvestiia Tomskogo politekhnicheskogo universiteta. Inzhiniring georesursov, 2009, vol. 315, no. 4, pp. 29-34.

38. Luksho V.A., Tiufiakov A.S., Grigor'ev L.Iu. Tekhnicheskie aspekty obespecheniia ekologicheskoi bezopasnosti ATS s gazovymi dvigateliami [Technical aspects of ensuring the environmental safety of vehicles with gas engines]. Trudy NAMI, 2009, no. 242, pp. 133-147.

39. Osinskaia K.Iu. et al. Issledovanie ekotoksichnosti prisadok i ikh vliianie na pokazateli kachestva dizel'nogo topliva [Research of ecotoxicity of additives and its effect on quality scores of diesel fuel]. Neftegazovoe delo, 2013, no. 11-3, pp. 117-122.

40. Larikov N.N. Teplotekhnika [Heat engineering]. 3nd ed. Moscow: Stroiizdat, 1985, 432 p.

41. Terent'ev G.A., Tiukov V.M., Smal' F.V. Motornye topliva iz al'ternativnykh syr'evykh resursov [Motor fuels from alternative raw materials]. Moscow: Khimiia, 1989, 272 p.

42. Lukanin V.N., Shatrov M.G., Kamfer G.M. et al. Teplotekhnika [Heat engineering]. Ed. V.N. Lukanin. 2nd ed. Moscow: Vysshaia shkola, 2000, $671 \mathrm{p}$.

43. Heilig L., Voß S. A scientometric analysis of public transport research. Journal of public transportation, 2015, vol. 18, no. 2, 8 p. DOI: $10.5038 / 2375-0901.18 .2 .8$

44. Kurnia J.C. et al. Prediction and innovative control strategies for oxygen and hazardous gases from diesel emission in underground mines. Science of the Total Environment, 2014, vol. 481, pp. 317-334. DOI: 10.1016/j.scitotenv.2014.02.058

45. Loboda E.L. et al. Otsenka masshtabov turbulentnosti $\mathrm{v}$ plameni pri diffuzionnom gorenii dizel'nogo topliva [Evaluation of the turbulence scale in a flame at the diffusion combustion of diesel fuel]. Vestnik Tomskogo gosudarstvennogo universiteta. Matematika i mekhanika, 2016, no. 4(42). DOI: 10.17223/19988621/42/9

\section{Библиографический список}

1. ПБ 06-111-95 Единые правила безопасности при разработке рудных, нерудных и россыпных месторождений полезных ископаемых подземным способом: утв. постановлением Госгортехнадзором России от 23.01.1995 № 4. - М., 1995.

2. ВНТП 13-2-93 Нормы технологического проектирования горнодобывающих предприятий металлургии с подземным способом разработки: утв. Комитетом Российской Федерации по металлургии (протокол от 27.01.1993 № 1) по согласованию с Госгортехнадзором РФ (протокол от 13.12.1992 № 4). - М., 1993.

3. Stinnette J. D., De Souza E. Establishing total airflow requirements for underground metal/non metal mines with tier IV diesel equipment // 23rd World Mining Congress and Expo. 2013.

4. Chang P., Xu G. Review of Diesel Particulate Matter Control Methods in Underground Mines // Proceedings of the 11th International Mine Ventilation Congress. - Springer, Singapore, 2019. - P. 461-470. DOI: 10.1007/978-981-13-1420-9_39

5. McGinn S. Controlling diesel emissions in underground mining within an evolving regulatory structure in Canada and the United States of America. - 2016.

6. Zhang H. A framework to develop a hybrid methodology for modeling of diesel particulate matter concentration in underground mine ventilation systems: dis. Laurentian University of Sudbury, 2019.

7. Coal miners exposed to diesel exhaust emissions / R. Reger [et al.] // Inhaled Particles V. - Pergamon, 1982. - P. 799-815. DOI: 10.1093/annhyg/26.8.799

8. The main components of vehicle exhaust gases and their effective catalytic neutralization / L.R. Sassykova [et al.] // Oriental
Journal of Chemistry. - 2019. - Vol. 35, № 1. - P. 110-127. DOI: $10.13005 / \mathrm{ojc} / 350112$

9. Mischler S.E., Colinet J.F. Controlling and monitoring diesel emissions in underground mines in the United States. 2009.

10. Halim A. Ventilation requirements for diesel equipment in underground mines-Are we using the correct values // 16th North American Mine Ventilation Symposium. - Golden, Colorado, 2017. - P. 1-7.

11. Villa T.F. Development of an unmanned aerial vehicle (UAV) system for in-situ characterization of combustion source emissions. - Queensland University of Technology, 2017. DOI: 10.5204/thesis.eprints. 114062

12. Правила безопасности при ведении горных работ и переработке твердых полезных ископаемых: Федеральные нормы и правила в области промышленной безопасности / утв. приказом Ростехнадзора от 11.12.2013 № 599 (с изменениями на 21 ноября 2018 года). - М., 2018.

13. ГОСТ Р 52368-2005 (ЕН 590:2009) Топливо дизельное ЕВРО. Технические условия. - М., 2005.

14. ГОСТ 32511-2013 (EN 590:2009) Топливо дизельное ЕВРО. Технические условия. - М., 2013.

15. ГОСТ 305-2013 Топливо дизельное. Технические условия (Переиздание). - М., 2013.

16. Ходяков А.А., Хлопков С.В., Бернацкий В.В. Физико-химические свойства дизельного топлива стандарта «Евро» // Журнал автомобильных инженеров. - 2017. № 1. - C. 40-43.

17. Двигатели внутреннего сгорания: в 3 кн. - Кн. 1: Теория рабочих процессов: учебник для вузов / В.Н. Луканин, К.А. Морозов, А.С. Хачиян [и др.]; под ред. В.Н. Луканина. 2-е изд., перераб. и доп. - М.: Высшая школа, 2005. - 479 с.

18. Орлин А.С. Двигатели внутреннего сгорания. Устройство и работа поршневых и комбинированных двигателей / под общ. ред. А.С. Орлина, М.Г. Круглова. 4-е изд., перераб. и доп. - М.: Машиностроение, 1990. - 289 с.

19. Круглов М.Г., Меднов А.А. Газовая динамика комбинированных двигателей внутреннего сгорания: учеб. пособие для студентов, обучающихся по специальности «Двигатели внутреннего сгорания». - М.: Машиностроение, 1998. - 360 c.

20. Двигатели внутреннего сгорания: учеб. для вузов по спец. «Строительные и дорожные машины и оборудование» / А.С. Хачиян, К.А. Морозов, В.Н. Луканин [и др.]; под ред. В.Н. Луканина 2-е изд., перераб и доп. - М.: Высшая школа, 1985. - 311 с.

21. Directive 97/68/EC of the European Parliament and of the Council of 16 December 1997 on the approximation of the laws of the Member States relating to measures against the emission of gaseous and particulate pollutants from internal combustion engines to be installed in non-road mobile machinery (Директива 97/68/ЕС Европейского Парламента и Совета от 16 декабря 1997 г. о сближении законов государств-членов, касающихся принятия мер против выбросов газообразных загрязнителей и твердых частиц из двигателей с внутренним сгоранием двигателей для установки на внедорожной мобильной технике) // Official Journal of the European Communities. - 1998. - L59/1. - C. 1-86.

22. Directive 2002/88/EC of the European Parliament and of the Council of 9 December 2002 amending Directive 97/68/EC on the approximation of the laws of the Member States relating to measures against the emission of gaseous and particulate pollutants from internal combustion engines to be installed in non-road mobile machinery (Директива 2002/88/ЕС Европейского Парламента и Совета от 9 декабря 2002 г. об изменении Директивы 97/68/ЕС о сближении законов государств-членов, касающихся принятия мер против выбросов газообразных загрязнителей и твердых частиц из двигателей с внутренним сгоранием двигателей для установки на внедорожной мобильной технике) // Official Journal of the European Communities. - 2003. - L35. - C. 1-54. 
23. Directive 2004/ 26/EC of the European Parliament and of the Council of 21 April 2004 amending Directive $97 / 68 / \mathrm{EC}$ on the approximation of the laws of the Member States relating to measures against the emission of gaseous and particulate pollutants from internal combustion engines to be installed in non-road mobile machinery (Директива 2004/26/EC Европейского Парламента и Совета от 21 апреля 2004 г. об изменении Директивы 97/68/EC о сближении законов государств-членов, касающихся принятия мер против выбросов газообразных загрязнителей и твердых частиц из двигателей с внутренним сгоранием двигателей для установки на внедорожной мобильной технике) // Official Journal of the European Communities. - 2004. - L146. - C. 1-107.

24. Code of Federal Regulations, 40. Part 89. 1999. CONTROL OF EMISSIONS FROM NEW AND IN-USE NONROAD COMPRESSION-IGNITION ENGINES. (Свод Федеральных нормативных актов, том 40, часть 89. Контроль выбросов новых и используемых внедорожных машин с двигателями внутреннего сгорания) [Электронный ресурс]. - URL: https://www.law.cornell.edu/cfr/text/40/part-89 (дата обращения: 10.02.2020).

25. Code of Federal Regulations, 40. Part 1039. 2012. CONTROL OF EMISSIONS FROM NEW AND IN-USE NONROAD COMPRESSION-IGNITION ENGINES. (Свод Федеральных нормативных актов, том 40, часть 1039. Контроль выбросов новых и используемых внедорожных машин с двигателями внутреннего сгорания) [Электронный ресурс]. - URL: https://www.govregs.com/regulations/ 40/1039 (дата обращения: 10.02.2020).

26. Временная инструкция по расчету количества воздуха, необходимого для проветривания рудных шахт. M., 1983.

27. Рудничная вентиляция: справочник / под ред. проф. К.З. Ушакова. - М.: Недра, 1988.

28. ГОСТ 17.2.2.01-84. Дизели автомобильные. Дымность отработавших газов. Нормы и методы измерений. М., 1984.

29. ГОСТ 31967-2012 Двигатели внутреннего сгорания поршневые. Выбросы вредных веществ с отработавшими газами. Нормы и методы определения (с Изменением № 1). M., 2012.

30. Горбунов В.В., Патрахальцев Н.Н. Токсичность двигателей внутреннего сгорания: учеб. пособие. - М.: Изд-во рудН, 1998. - 214 с.

31. Лиханов В.А., Лопатин О.П. Исследование токсичности отработавших газов дизеля с промежуточным охлаждением наддувочного воздуха при работе на природном газе // Строительные и дорожные машины. - 2016. № 9. - С. 30-34.
32. Голохваст К.С., Чернышев В.В., Угай С.М. Выбросы автотранспорта и экология человека (обзор литературы) // Экология человека. - 2016. - № 1.

33. овалевский В.В., Фролов А.В. Оценка экологической безопасности автомобильных дизелей термохимическирезистивным методом // Экологические системы и приборы. 2007. - № 1. - С. $1-6$.

34. Экологические показатели дизельных двигателей с разными условиями смесеобразования при работе на биодизельном топливе / В.Ф. Шапко [и др.] // Новые материалы и технологии в машиностроении. - 2011. - № 13. C. $150-153$.

35. Исследование качественного состава твердых частиц выхлопов ДВС автомобилей без пробега / В.В. Чернышев [и др.] // Горный информационно-аналитический бюллетень (научно-технический журнал). - 2014. - № S4-11. - С. 160-167.

36. Камалдинов В.Г., Марков В.А., Драгунов Г.Д. Оценка показателей рабочего цикла НССІ-двигателя с наддувом при различных частотах вращения коленчатого вала и нагрузках // Известия высших учебных заведений. Машиностроение. 2014. - № 6 (651). - С. 25-34.

37. Кулешов В.К., Бразовский В.В., Баранов В.А. Контроль параметров продуктов сгорания в фильтрационных установках // Известия Томского политехнического университета. Инжиниринг георесурсов. - 2009. - Т. 315, № 4. - С. 29-34.

38. Лукшо В.А., Тюфяков А.С., Григорьев Л.Ю. Технические аспекты обеспечения экологической безопасности АТС с газовыми двигателями // Труды НАМИ. - 2009. - № 242. - С. 133-147.

39. Исследование экотоксичности присадок и их влияние на показатели качества дизельного топлива / К.Ю. Осинская [и др.] // Нефтегазовое дело. - 2013. - № 11-3. - С. 117-122.

40. Лариков Н.Н. Теплотехника: учеб. для вузов. 3-е изд., перераб. и доп. - М.: Стройиздат, 1985. - 432 с.

41. Терентьев Г.А., Тюков В.М., Смаль Ф.В. Моторные топлива из альтернативных сырьевых ресурсов. - М.: Химия, 1989. - 272 c.

42. Теплотехника: учеб. для вузов / В.Н. Луканин, М.Г. Шатров, Г.М. Камфер [и др.]; под ред. В.Н. Луканина. 2-е изд., перераб. - М.: Высш. шк., 2000. - 671 с.

43. Heilig L., Voß S. A scientometric analysis of public transport research // Journal of public transportation. 2015. - Vol. 18, № 2. - P. 8. DOI: 10.5038/2375-0901.18.2.8

44. Prediction and innovative control strategies for oxygen and hazardous gases from diesel emission in underground mines / J.C. Kurnia [et al.] // Science of the Total Environment. 2014. - Vol. 481. - P. 317-334. DOI: 10.1016/j.scitotenv.2014.02.058

45. Оценка масштабов турбулентности в пламени при диффузионном горении дизельного топлива / Е.Л. Лобода [и др.] // Вестник Томского государственного университета. Математика и механика. - 2016. - № 4 (42). DOI: 10.17223/19988621/42/9

Please cite this article in English as:

Grishin E.L., Zaitsev A.V., Kuzminykh E.G. Ensuring Safe Workplace Conditions when Working Equipment with Internal Combustion Engines by Ventilation in Underground Mines. Perm Journal of Petroleum and Mining Engineering, 2020, vol.20, no.3, pp.280-290. DOI: $10.15593 / 2712-8008 / 2020.3 .8$

Просьба ссылаться на эту статью в русскоязычных источниках следующим образом:

Гришин Е.Л., Зайцев А.В., Кузьминых Е.Г. Обеспечение безопасных условий деятельности сотрудников по фактору вентиляция в подземных рудниках при работе техники, оснащенной двигателями внутреннего сгорания // Недропользование. - 2020. - T.20, №3. - C.280-290. DOI: 10.15593/2712-8008/2020.3.8 